\title{
WILLIAM WARBURTON AND THE EIGHTEENTH CENTURY ENGLISH ENLIGHTENMENT
}

\author{
Pervin YíĞİT*
}

\begin{abstract}
$\ddot{O} z$
William Warburton ve 18. Yüzyıl İngiliz Aydınlanması

İngiliz Aydınlanması, 18. yüzyıl Avrupa'sındaki birçok aydınlanma çeşidinden biridir ve her aydınlanma gibi İngiliz Aydınlanması'nın da kendine özgü bir yapısı vardır. Bir yandan var olan düzeni korumaya çalışırken, bir yandan da dine karşı tutumuyla doğal bilimlerdeki ilerlemeleri, bireysel özgürlükleri ve rasyonalizmi desteklemeye çalışmaktadır. Fakat, 18. yy. Britanya'sı aynı zamanda dini karışıkların hem kiliseyi hem de devletin otoritesini bozma tehlikesi yarattığı bir dönemdir. İngiliz Aydınlanması, Avrupa'nın diğer yerlerinde olduğu gibi dine karşı bir tepki olarak şekillense de, dönemin etkili din adamları aracılığıyla dini ve siyasi otoritenin uzlaşma planlarının doğmasına ve Anglikan kilisesini güçlendirme sürecine de tanıklık etmiştir. Bu koşullar altında şekillenen İngiliz Aydınlanması, ülkenin refahı için rasyonaliteyi ve dini, devleti ve kiliseyi ortak bir zeminde buluşturmaya çalışan entelektüellerin çabalarından etkilenmiştir. Bu çalışmada dönemin önemli kimliklerinden William Warburton'un eserleri aracılığıyla, bu çabalar incelenmiş ve ayrıca siyasal ve sosyal düzenin korunması amacıyla kilise ile devlet arasında kurulmaya çalışılan ittifak ele alınmıştır. Bu çalışmada, Warburton'un gözünden İngiliz Aydınlanması'nın Hristiyan yorumlaması aktarılmış, Anglikan kilisesinin bir yandan Aydınlanma'yı desteklerken, bir yandan da siyasi ve ahlaki olarak devleti ve kiliseyi korumak için yapması gereken uzlaşma planı detaylı olarak incelenmiştir.
\end{abstract}

Anahtar Kelimeler: İngiliz Aydınlanması, William Warburton, uzlaşma, din, siyasal düzen

\begin{abstract}
English Enlightenment was a form of enlightenment in the eighteenth century Europe and it has a peculiar character like other forms. It was trying to preserve the existing order and at the same time it was to support rationalism, individual free will and the advance of natural science by means of its attitude toward religion. However, $18^{\text {th }}$ century Britain was a period in which religious controversies were regarded as direct perils both to the authority of church and state. Although English Enlightenment was emerged as a movement against the sole authority of religion like other places in Europe, it also witnessed the attempts of reconciling the civil
\end{abstract}

\footnotetext{
* Assist. Prof. Dr., Arkin University of Creative Arts and Design, Department of New Media, Kyrenia, TRNC. E-posta: pervin.yigit@arucad.edu.tr. ORCID: 0000-0002-8060-8563.

(Makale Gönderim Tarihi: 17.05.2019 - Makale Kabul Tarihi: 06.12.2019)
} 


\section{Pervin YİĞITT}

authority and the ecclesiastical authority and the re-establishment of the Anglican Church as the established church by means of the influential Anglicans. English Enlightenment that gained a character under these conditions was affected by the intellectuals' attempts to make an alliance between rationalism and religious enthusiasm and state and church. In this paper, these attempts are investigated through the works of one of the most influential character of the period; William Warburton. I aim to explore the reasons why an alliance between church and state emerged for maintaining the political and social order in the long eighteenth century. For this end, Warburton's Christian interpretation of the English Enlightenment was examined and finally his reformation plan, which was introduced to support Enlightenment ideas and to preserve the power of the church and the state all at once were studied.

Keywords: English Enlightenment, William Warburton, alliance, religion, political order

\section{Introduction}

\section{"In England, Enlightenment remained within a religious matrix". 1}

According to J. G. A. Pocock, there is no unitary definition of the Enlightenment. Rather, there are different forms of it and English Enlightenment is only one of these different forms. Some historians like P. Langford, R. Porter, K. Haakonssen, B. Young and S. Gilley claimed that Enlightenment in England was not by definition an anti-religious project for the liberation of mind and reconstruction of society. It is both clerical and conservative. ${ }^{2}$ Although it originated in religious controversies, the English Enlightenment did not completely emerge as a rebellion against the hegemony of religious principles. Thinkers who are defending the conservative character of the English Enlightenment argued that the church needed to be defended against both to the varieties within the church and to external threats in the given period. Although Anglican Church could be regarded as one of the most significant factor that led English Enlightenment to emerge, the religious men in the eighteenth century tried to re-establish and strengthen Anglican Church and that attempt could be regarded as the reflection of the clerical aspect of English Enlightenment. Since no study on Anglican's interpretation of English Enlightenment could be reached in Turkey, this paper would provide the clerical point of view for the English Enlightenment. Moreover, by considering it as the product of the Anglican system, its attitude towards religion in general and to the established church in particular need to be investigated besides the studies of French and Scottish Enlightenments in Turkey.

\footnotetext{
${ }^{1}$ Pocock 1997, p. 26.

${ }^{2}$ For more on the nature of Enlightenment in Britain, see Langford 2002, pp. 76, 99; Porter 1981, pp. 1-18; Haakonssen 1996, pp. 2-3; Young 1998, pp. 214-215; Gilley 1981, pp. 103-121.
} 
English Enlightenment was a product of the Anglican system in the sense that, the civil as well as the ecclesiastical authority endeavoured to conserve the existing order. In order to explore that clerical character of the English Enlightenment and to understand how the Anglican religious men tried to make an alliance between the church and state for the preservation of the Anglican Church, the works of William Warburton (1698-1779) need to be discussed in detail.

Warburton was an influential theologian who epitomizes the eighteenth century England. ${ }^{3}$ His rational philosophy, prudential ethics, intellectualist conception of religion, dislike of enthusiasm, cultivation of the spirit of inquiry and insistence on toleration reflect the characteristics of the eighteenth century England. Apart from discovering the features of the century, an analysis of Warburton indicated how the Anglicans attempted to maintain the establishment in England.

The Enlightenment in England could be seen as a movement which contained both rationalism and religious enthusiasm by means of Anglicans attempts in general and Warburton's plan in particular. William Warburton and his circle $^{4}$ tried to preserve the British ${ }^{5}$ constitution from the effects of intolerance, superstition, religious enthusiasm and animosities in order to provide durability for both the church and the state. Their works gave a Christian context to the English Enlightenment. Moreover, they tried to strengthen the church during the English Enlightenment by concentrating on the alliance between the British constitution and the Anglican Church. ${ }^{6}$

In the eighteenth century, Britain was experiencing success in international arena, increase in economic conditions, improvement in education, and developments in arts and sciences. However, the picture of Britain was not promising because those improvements and especially the advance of natural science led religion to lose its crucial role in maintaining social order. Since the age was the age of scientific development and religious toleration, it is necessary to highlight that developments in philosophy and science and the growing popularity of rationalism had encouraged non-conformists to have heterodox opinions and private judgement, ${ }^{7}$ and directed them to become absolute threats to social order in the given period. That is to say, the insistence

\footnotetext{
${ }^{3}$ Evans 1932, pp. 2-3.

${ }^{4}$ For more on Warburton circle, see Evans 1932 and Yiğit 2017.

${ }^{5}$ In the paper, I am defining Enlightenment as English Enlightenment to differentiate it from French and Scottish. However, for the constitution, I am not saying "English" rather prefer "Great Britain" as the Act of Union had passed in 1707.

${ }^{6}$ For more information, see Haakonssen 1996, pp. 2-3; Langford 2002, p. 76.

${ }^{7}$ Wykes 1996, p. 122.
} 


\section{Pervin YİĞİT}

of reason and secularization and the decay of religion, which caused licentiousness, vice, and corruption had weakened the privileged status of the established Church and the subjection to the state and consequently led internal divisions within the church to arise. ${ }^{8}$

In the 18th century Anglican tradition was challenged by nonconformists. For the religious men in the Anglican Church, the threats to Anglicanism would cause divisions in church and society and finally they would cause corruption in social and political order. Therefore, Anglicans like William Warburton regarded Protestant dissenters, Roman Catholics, deists, freethinkers and atheists as dangers for the stability of British constitution and they tried to protect Anglican Church for the sake of the political order in the enlightenment era.

\section{English Enlightenment and Anglicanism}

Anglicanism based on the Scripture to achieve salvation, in other words the theological appeal of Anglicanism was only to Scripture. ${ }^{9}$ For Anglicans, while Church of Rome rests on the authority of God solely by ignoring the individuality of the believers, Anglican Church gave importance to individual free will apart from the power of God. ${ }^{10}$ God is the one and only judge in Anglicanism as well, but what Anglicanism emphasized was the capacity of human reason and free will and thus, Anglican thought was totally based on the interpenetration of the secular and the sacred in the make-up of the cosmos. Since God, nature and humanity seemed to be in dynamic interaction, happy or holly life could only be achieved through reason, human free will and the idea of God in Anglicanism.

In this light it could be stated that Anglicanism was an important factor that made the birth of enlightenment in England possible. Afterwards, during the enlightenment period, Anglicans tried to prove Anglican Church as the only established church in Britain in order to achieve a religious tranquillity, to maintain religion's role in society, to eliminate the controversies within the church and thus, to allow the church to support political and social order in Britain.

The English Enlightenment aimed to improve human condition and in order to do that it had concerned with the relationship between church, state and the power of the king in the given period. ${ }^{11}$ Since the church had "socially and culturally central role in the lives of the English", ${ }^{12}$ the understanding of English

\footnotetext{
${ }^{8}$ O’Gorman 1997, p. 294.

${ }^{9}$ Neill 1958, p. 417.

${ }^{10}$ Walsh and Taylor 1993, p. 56.

${ }^{11}$ Pincus 2006, p. 27.

12 Pincus 2006, p. 26.
} 
Enlightenment will remain incomplete if religion is not integrated into its history, since Anglicanism was not only theology in the history of Great Britain but also one of the most important pillars of the British constitution. ${ }^{13}$ The submission to the state and to the church were both justified through Anglican tradition and consequently Anglican thought was used to strengthen the public order in the long eighteenth century in England.

Moreover, the Glorious Revolution (1688-1689), happened in the previous century, could not be regarded only as a war of religion, rather it should be treated as a struggle of the Enlightenment ${ }^{14}$ which was "dialectic between Enlightenment and Counter-Enlightenment tendencies, especially evinced in religious thought". ${ }^{15}$ That is to say, The Glorious Revolution was a restorative event that aimed to preserve "England's ancient polity and England's Protestant religion", ${ }^{16}$ and to maintain the British Constitution from corruption.

Regarding English Enlightenment as a completely secular movement or an absolutely clerical one would both be incomplete. During the enlightenment era, religion was used as a political tool in the political state by the Anglican Church in the eighteenth century. Therefore, that attempt of maintaining Great Britain as a peaceful constitution should be analysed by means of the ecclesiastical authority as well.

\section{Anglican's interpretation of religious conditions in the 18th century Great Britain}

As mentioned above, Anglican tradition was challenged by religious controversies, the dissenters, atheists and Catholics in the given period. Warburton regarded these challenges as dangerous threats to Anglicanism and as possible causes of the corruption in social and political order. Before investigating what Anglicans had proposed for the religious tranquillity, it will be beneficial to go to the fountainhead of the controversies and look at the main policies regarding religious issues after the Glorious Revolution and understand the crucial link between the state and Anglican Church in administration.

Revolution in 1688-1689 substituted a parliamentary elective kingship and swept the monarchy rested on ruling by hereditary right away. ${ }^{17}$ Therefore, the law and parliament limited the authority of the monarchy and its temporal spiritual authority was rejected. This also led church to lose its legal monopoly

\footnotetext{
${ }^{13}$ O'Gorman 1997, p. 165.

${ }^{14}$ Pincus 2006, p. 27.

${ }^{15}$ Young 1998, pp. 214-215.

${ }^{16}$ Pincus 2006, p. 6.

${ }^{17}$ Sykes 1934, p. 285.
} 


\section{Pervin YíĞIT}

over the religious issues. Although, after the revolution the established church retained important privileges, it was subordinated to the state under the terms of the 1689 settlement. Since the sovereignty was no longer legitimated by religion, the belief that the government could be maintained by other means than religion had been arisen and consequently religion had started to use its dominant power in the eighteenth century.

Rationality replaced the importance of religion. It is necessary to mention that in enlightenment, God as interventionist was replaced by the idea of God who bestowed reason upon human beings. ${ }^{18}$ In other words, God was regarded as "a beneficent Newtonian hero who had designed the world as a system of benevolence". ${ }^{19}$ Due to the rising influence of rationalism, and the influence of John Locke's philosophy, there was a tendency to believe that "the credentials of every religion must be submitted to reason". ${ }^{20}$ Religion was in need of being more rational and non-mysterious, and therefore there was an attempt to question the fundamentals of revealed religion and to use reason to test the revealed truth.

Locke's assertion on the limits of human knowledge and his rejection of innate ideas threatened both the religious and political authorities. In his Essay on Human Understanding (1689), Locke discussed how human mind works and he sets limits to human understanding. Moreover, he rejected the possibility of innate ideas by claiming, "No man's Knowledge here can go beyond his experience". ${ }^{21}$ Although the idea of God could not be found naturally in human mind, Locke's examination was not to reject faith. The divine implantation of God was replaced by human's ability in forming the notion of God through reason. In addition to this, his reliance on scripture and his insistence on the will of God as the foundation of morals precluded his elimination of innate ideas from being censured as the threat to moral order.

Explicitly, Locke's philosophy contributed to the developments in experimental knowledge. Since human beings gained confidence in their intellectual capacities to achieve knowledge independent from God, they began to discover new areas of nature. Accordingly, the interest in human knowledge substituted the interest in metaphysical world. However, the reliance on reason and experimental knowledge did not harm the idea of God in Locke's philosophy. Therefore, it contributed to the Anglican's project for the preservation of the idea of God despite the growing interest in empirical knowledge.

\footnotetext{
${ }^{18}$ Fitzpatrick 1996, p. 64.

${ }^{19}$ Fitzpatrick 1996, p. 64.

${ }^{20}$ Plummer 1910, p. 91.

${ }^{21}$ Locke 1726, p. 48.
} 
Nevertheless, Locke's Letter on Toleration (1689) weakened the link between state and church. For him, state aimed to protect external interests like that of life, liberty and welfare. However, the church deals only with the salvation of souls and the state could not be allowed to engage in ecclesiastical affairs. ${ }^{22}$ Unsurprisingly "this divorce between the state and the church was considered as a direct threat to the Anglican Establishment in the conditions of the period" ${ }^{23}$ Locke suggested leaving religious belief to private conscience of human beings and providing toleration to different sects and religion. Although they seemed to encourage non-conformist to have heterodox opinions, they supported individual liberty and religious tolerance in Anglican politics.

Furthermore, Anglican politics had refuted religious enthusiasm in terms of Lockean tradition. Enthusiasm that challenged the clerical and magisterial authority was opposed by means of mind's incapacity of perceiving metaphysical and religious essences. ${ }^{24}$ The replacement of the religious enthusiasm by the reasonableness of Christianity made Protestantism acceptable to all rational beings. There was no need for papal authority or an arbitrary power because human beings had the ability to interpret bible by reasoning. Locke also mentioned the significance of freedom and consent by means of the reasonableness of Christianity. Reason was admitted as the criterion of judgement and the church considered as a voluntary society that people freely decided to enter. Therefore, for him, reasonable belief turned to be the coordination of reason and revelation. ${ }^{25}$

Due to the influence of John Locke (1632-1704), religious society began to be treated as "a free and voluntary society", ${ }^{26}$ in which everyone had right to join any particular church and worship according to their own beliefs. ${ }^{27}$ This plurality in religious thought made the sovereignty unable to be legitimized by religion therefore the belief that the government could be maintained by other means than religion was emerged and naturally, for Anglicans religion had started to lose its dominant power in eighteenth-century England.

As one of the most influential religious man of the period, Warburton thought that both the church and state were in danger. Therefore, both he and his followers wanted to make a reformation plan for the treatment of the status of the Church for the sake of the public wealth. Before talking about that plan, it would be beneficial to discuss the Acts that passed before that period in order to understand the reasons why it was necessary to maintain the Anglican Church as the established church of the constitution.

\footnotetext{
${ }^{22}$ Locke 1788, p. 24.

${ }^{23}$ Yigit and Özkutlu, 2017, 314.

${ }^{24}$ Pocock 2007, p. 87.

${ }^{25}$ Sorkin 2010, p. 12 .

${ }^{26}$ Locke 1740, p. 11.

${ }^{27}$ Locke 1740, p. 11.
} 


\section{The political conditions and the Acts}

The Acts could indicate us the Church's status and political conditions before the Enlightenment period and clarify the Anglican's political worries that encourage Anglicans to introduce the alliance between church and state in the eighteenth century.

The first important act entitled An Act for "preventing dangers which may happen from Popish Recusants" ${ }^{28}$ was passed in the reign of Charles II in 1672. It was to preserve "the only protestant state by which England could expect to be supported in the defence of her religion and liberties". ${ }^{29}$ In the circumstance of this time the protestant subjects were frightened of the influence of Roman Catholicism therefore the act was designed to declare "an intention to prevent dangers from Popish recusants in particular, and an intention of quieting the minds of his Majesty's good subjects, disturbed also with the apprehension of other dangers" ${ }^{30}$ Although it seems that it was only against popish recusants, its provision affected equally all dissenters. ${ }^{31}$ When the test act was passed, it depended on a bill entitled "A bill for the ease of protestant dissenters" which abridged the civil rights of the dissenters. ${ }^{32}$ Since it was to secure the English Constitution against threats of all nonconformist parties, not only Papists, it is not difficult to realize that the Dissenters were also the objects of this act. ${ }^{33}$ By means of this Act, "persons ill affected to the established Church [were] excluded from certain places of trust and authority", ${ }^{34}$ and the members of the established church had gained the "firstclass citizenship". ${ }^{35}$ Shortly, this Act was to remove the mischiefs like the divisions in religious society to maintain the power of the established church.

Since this act created inequality for dissenters and favoured the principle of uniformity in religion, it was removed in the revolutionary period and another act, called Act of Toleration, was passed in 1689. Although it restricted religious liberty of Roman Catholicism, it guaranteed religious toleration to certain Protestants nonconformists. Actually, it allowed nonconformists to have the right of worship "at the price of the continuation of certain civil disabilities". ${ }^{36}$ What is important is that it was an attempt to approve religious diversity by undermining religious uniformity. ${ }^{37}$

\footnotetext{
${ }^{28}$ Horsley 1790, p. vii.

${ }^{29}$ Horsley 1790, p. viii.

${ }^{30}$ Horsley 1790, p. 47.

${ }^{31}$ Horsley 1790, p. 42.

${ }^{32}$ Horsley 1790 , p. ix.

${ }^{33}$ Horsley 1790, p. 43.

${ }^{34}$ Horsley 1790, p. 36.

${ }^{35}$ Walsh and Taylor 1993, p. 61.

${ }^{36}$ Grell and Porter 2000, p. 11.

${ }^{37}$ Langford 2002, p. 83.
} 
Afterwards, in 1711 The Occasional Conformity Act, called an "Act for Preserving the Protestant Religion by Better Securing the Church of England as by Law Established" ${ }^{38}$ was passed to restrict the political powers of dissenters. The Schism Act of 1714 also aimed to prevent the influence of the dissenters by restricting their education and to destroy "the continued existence of Dissent since it sought to create an Anglican monopoly in education by excluding Dissenters from teaching". ${ }^{39}$ In this light, it could be stated that the British Establishment tried to make a clear distinction between conformists and nonconformists to exclude the latter ones for preserving the Anglican tradition and the position of the church.

The unknown author of the The Occasional Paper upon the Subject of Religion, and the Church Establishment; and the present attempts against them stated that it was necessary to make such a "[d]istinction between two Parties in Point of Civil Power and Privileges". ${ }^{40}$ Thus, it seems that if any religious establishment is essential in a political state, the conformists and nonconformists have to be differentiated for the sake of the established religion. It is worth quoting this unknown author to grasp how the dissenters were identified in the eighteenth century. The dissenters were "a Body of Men agreeing with [Anglicans] in all Points relating to our Civil Establishment, and differing with [Anglicans] only in some Points of Church Government; in Consequence of which they are broken off from the National Worship, and have set up a Worship of their own". ${ }^{41}$

As was mentioned above, differentiating dissenters from the members of the established church was guaranteed by the Corporation and Test Acts and afterwards they were repealed and the dissenters were eased by Toleration Act. Due to the influence of Locke's ideas which suggested seeing religion as a matter entirely of private concern, only related with conscience, ${ }^{42}$ the dissenters were "left free to worship God according to their own Consciences, under an absolute Exemption from Penalties of all Kinds". ${ }^{43}$

However, even the toleration act did not give dissenters the right of admission to offices of trust and power in the state. All those acts have undeniable influence on the preservation of the church in this period, in which the Church reached its nadir and the spiritual life was in need of revival ${ }^{44}$ That

\footnotetext{
${ }^{38}$ Neill 1958, p. 181.

${ }^{39}$ Wykes 1996, p. 102.

${ }^{40}$ Anonymous 1735 , p. 4.

${ }^{41}$ Anonymous 1735, p. 4.

${ }^{42}$ For more on Locke's ideas on religion, see Locke 1788.

${ }^{43}$ Anonymous 1735 , p. 5.

${ }^{44}$ Watson 1863, pp. 7, 124.
} 
is to say, although the establishment was not made through these acts, it was protected by these Acts; in Horsley's words, "just as a Gentleman's property in his grounds is not made, but it is guarded by his park-fence and by his garden-wall". ${ }^{45}$

At this point, it is necessary to talk about Sir Robert Walpole, the first Prime Minister of Great Britain (1721-1742), who introduced policies regarding Church's status and protestant succession. ${ }^{46}$ Evidently Sir Robert Walpole, as the representative diplomat of this age, made Britain enjoy an "unexampled spell of peace and outward prosperity". ${ }^{47}$ In order to achieve religious tranquillity, he tried to consolidate the Protestant succession and eliminate the religious persecution and divisions by means of religious toleration. Although he was censured as he caused bribery, corruption, intimidation and jobbery in church, the supremacy of the Anglican Church, which he aimed to confirm, was treated as the main support of Walpolean regime and his undeniable success. ${ }^{48}$ For him, his policies were to preserve the dominant power or status of the church from the outside violence, but what is criticized by the religious men is that he tried to protect the church without allowing changes in ecclesiastical affairs because he saw the reforms within the church as the causes of commotion. ${ }^{49}$ Therefore, Anglican intellectuals considered Walpole's attitude towards nonconformists as the most important factors in arising controversies in Church and his standpoint against the necessity of reforms led Walpole's administration to be disapproved as "a chilling effect upon the development of the national Church". ${ }^{50}$

This is the reason why, the historians saw the disappointment of ecclesiastical policies of Walpole as the crucial reason of the steady decline of the Church and regarded those policies as dangerous as the threats of deism, atheism and dissenters. ${ }^{51}$ In other words, it could be stated that apart from the internal divisions within the church and the external threats, the ill treatment of the Church received in Walpolean years had accelerated the decline in the dominance of the church. ${ }^{52}$

What Walpole tried to do was to support religious toleration to silence the religious controversies. The calmness of the period was the evidence of his

\footnotetext{
${ }^{45}$ Horsley 1790, p. 53.

${ }^{46}$ For the most up to date biography see Taylor 2009.

${ }^{47}$ Watson 1863, pp. 287-288. For more information about the peace in this period see: O'Gorman 1997, p. 65.

${ }^{48}$ O'Gorman 1997, pp. 75-85.

${ }^{49}$ Plummer 1910, p. 88.

${ }^{50}$ Plummer 1910, p. 72.

${ }^{51}$ Langford 2002, p. 93.

52 Plummer 1910, p. 4.
} 
success in maintaining a peaceful society. However, the tranquillity of the period was the proof of stagnation rather than the cessation of those strong and persistent controversies on religious issues.

It is necessary to highlight that the acts and bills that passed during this period were censured as being artificial supports, which actually did not serve the true interest of the church. ${ }^{53}$ Consequently, Walpole's administration could be criticized as leading corruption in the society; it is obvious that Britain could not be defined as a peaceful and well-ordered society as it is clearly shown during the Jacobite Rebellion of 1745. At this point, Anglicans had started to worry about the future of the Anglican Church and the establishment.

\section{Warburton's Reformation Plan}

Under these conditions mentioned above, Warburton was worried and introduced a programme for reformation. When we look at the political worries of Anglicans that emerged from the decay of religion, it is obvious that Anglicans needed to defend religion in general and protestant principles in particular to secure their dominance over rationalism and non-conformists. As an Anglican, what worried Warburton were the forthcoming results of those religious controversies because he believed that the happy establishment of Great Britain was going to be destroyed due to political and moral disintegration that caused by fragmentation within the church. In order to prevent such a corruption in the establishment and provide stability for the state, Warburton tried to defend the privileged status of the Anglican Church as a safeguard against all political and moral evils and anarchy. For him, the remedy for social and moral disintegration and guard of the national unity of Great Britain is the alliance between state and church.

William Warburton, regarded the defence of Anglicanism as his duty he owed to his country, ${ }^{54}$ and he aimed to prevent the steady and dreadful decline of the Church and the growing of infidelity. In order to offset the actual threats against the church, he thought that religion should be maintained against atheists and the divided character of the church caused by non-conformists should be eliminated. What he argued for regarding the religious debates of the time was the preservation of Protestantism and the Anglican Church's privileged status. It was clear, for Warburton, that the decay in religious belief and religious divisions would lead corruption in England soon or later. Therefore, he tried to find a cure for this forthcoming danger and introduced the necessity of the alliance of church with the state to protect the constitution

\footnotetext{
${ }^{53}$ Plummer 1910, p. 7.

${ }^{54}$ Warburton 1746a.
} 
against the internal and external threats. In order to defend such an alliance, he had published The Alliance between Church and State in 1736.

Warburton stated that both religion and government "ordained to one end, to perfect HUMANITY", ${ }^{55}$ but there is a need of a policy by which the church was governed in order to direct the church to the end of government. ${ }^{56}$ It could be stated that, this commitment rationalized his idea on the necessity of an alliance between church and state. The Alliance was so well structured that, in 1790, Horsley claimed that it was "one of the finest specimens that are to be found perhaps in any language, of scientific reasoning applies to a political subject". ${ }^{57}$

In the circumstance of this time, The Alliance served for eliminating the risk of contradiction between the state and the church because it made their interests become inseparable. When the lawgiver sought his interest in the alliance with a particular church, civil magistrate gained ecclesiastical supremacy through this alliance. When church allied with the state and sought for the protection of the lawgiver the clergy became dependent on the state and could not have contradictory interests. ${ }^{58}$ Therefore, by stating that "the Aid they lent each other so reciprocal, that, whenever the common Enemy formed Schemes to the Prejudice of the one, he always began with some Attempts against the other", ${ }^{59}$ Warburton attempted to establish a strong link between the state and the church in order to secure the well-being and happiness of civil society by means of the functionalist role of the church.

According to Warburton, "[t] $]$ he State was induced to seek this Alliance as the necessary Means to improve the Usefulness, and to apply the Influence of Religion in the best Manner". ${ }^{60}$ That is, the state should use religion for its own sake; clearly, religion could be used to prevent the mischiefs in the civil society, which could arise when the state was left in its natural and independent condition. ${ }^{61}$ After such interdependence between the church and the state was achieved, the state served the interests of the established church and "preserve [the church] by all lawful ways, from outward Violence". ${ }^{62}$ Therefore, for church, engaging an alliance with the state was to secure its well-being. It becomes clear in Warburton's words; "For by the Equity of our Civil Constitution the Consciences of Men are not only left in Freedom, but also protected in it". ${ }^{63}$

\footnotetext{
${ }^{55}$ Warburton 1766, p. iii.

${ }^{56}$ Warburton 1746b, p. 3.

${ }^{57}$ Horsley 1790, p. i.

${ }^{58}$ Warburton 1736, p. 74. See also Horsley 1790, p. 18.

${ }^{59}$ Warburton 1746b, p. 8.

${ }^{60}$ Warburton 1736, p. 60.

${ }^{61}$ Warburton 1736, p. 63.

${ }^{62}$ Warburton 1736, p. 68.

${ }^{63}$ Warburton 1745, p. 6.
} 
The truth seems that since the church had no coercive power, it needed the protection of a legitimate state to survive in peace without the threat of foreign impediments and this was possible if and only if the church allied with the state. For this reason, Warburton insisted that the state "not only promises not to injure the Church, but to serve it; that is, protect it from the Injuries of other Religious Societies, which exist or may arise in the same State" ${ }^{64}$

In addition to this, Warburton introduced reasons why he believed that it was impossible for a state to achieve stability without the aid of the church. The one of the most crucial reason was the nature of human beings. For him, "Nature has made [The Appetite of Self-Preservation] the strongest of all", and this appetite which was identified as the "most indispensably necessary" 65 motivated human beings to behave selfishly. Due to the weakness of the human nature, people in the state of nature had tendency to have every need more than what was necessary for his own being. Since he "never thought he had sufficiently provided for his own Being, till he had deprived his Fellows of the free Enjoyment of theirs", ${ }^{66}$ an establishment was necessary to turn the balance for the sake of all rational animals. However, civil societies without the religious one or the religious one without the civil were equally unsatisfactory in achieving this balance among all human beings. To be precise, before civil society was established, only religion was not adequate to avoid men from acting according to their own interests and pleasures. In the same way, after it was established, the state could not be successful without the aid of the religion. In Warburton's words, in the state of nature "RELIGION alone was an ineffectual Remedy to moral Disorders, so now SOCIETY, without other Assistance, would be equally insufficient" ${ }^{67}$ He stated many reasons to reinforce this point. Firstly, he said that, civil laws did not pay attention to virtues like gratitude, hospitality and charity since they could not affect the society directly. Secondly, established laws could not be extended to restrain the violation of rights such as fornication and thus, another sanction was required to regulate moral lives of the subjects. Thirdly, civil laws could not replace the principle of self-love in the state of nature with the love of country in a society, which was essential for the preservation of the country. Fourthly, society inflamed inordinate appetites whose satisfactions were difficult and this led disintegration among the subjects. Lastly, he talked about the crucial role of the sanctions and stated that society had sanction of punishment only, whereas one of reward was also necessary for a peaceful order. ${ }^{68}$

\footnotetext{
${ }^{64}$ Warburton 1736, p. 68.

${ }^{65}$ Warburton 1736, p.4.

${ }^{66}$ Warburton 1736, p. 5.

${ }^{67}$ Warburton 1736, p. 7.

${ }^{68}$ Warburton 1736, pp. 8-10
} 


\section{Pervin YíĞIT}

Now, it is time to talk about the necessity of the sanction of rewards for Warburton's moral theory in order to comprehend the essential role of God in social order. It seemed that the most influential advantage of religion's assistance with the state was the sanction of rewards, which had the ability to secure the observance of the civil laws. Warburton insisted that the end of the society, which was the happiness for all, could not be reached without sanctions of both punishment and reward. Since only religion "can supply the Sanction of Rewards, which Society wants, and has not, Religion is absolutely necessary to civil government" the Power of Religion; which teaching an over-ruling Providence, the Rewarder of good Men, and the Punisher of ill, can oblige to the Duties of imperfect obligation, which human Laws overlook; and teaching, also, that this Providence is omniscient, that it sees the most secret Actions and Intentions of Men, and has given Laws for the perfecting their Nature, will oblige of those Duties of perfect Obligation, which human Laws cannot reach, or sufficiently enforce. ${ }^{70}$

Therefore, the sanction of reward was regarded as the cement of the society, which inculcated men to obey both to civil and religious laws. A civil magistrate could enforce people to obey the written laws but if people obey the sovereign and his laws only because of the power it had over the subjects, a social order would turn to be impossibility. That is to say, the subjects should believe that it was the right of the sovereign, not only its power, which makes them, obey. For this reason, Warburton stated that when Society was established it was necessary that human Laws should be enforced on a Principle of RIGHT as well as POWER; that is, on a Principle, which would make them obeyed for conscience sake. ${ }^{71}$

As a result, sanctions and thus religious laws are necessary as well as the civil ones and different from the written laws, only the unwritten ones could enforce the hearts and minds of people due to the authoritative character of divine reason. During the Jacobite rebellion, he repeated the role of religion in the moral order and stated that it was to "teach Men subjection on Motives of Piety and true Holiness, not only for Wrath, but also for Conscience sake". ${ }^{72}$ By means of the "Truth and Purity of Faith", ${ }^{73}$ he aimed to rationalize the subjection of people and secure civil justice in Great Britain.

\footnotetext{
${ }^{69}$ Warburton 1736, p. 16.

${ }^{70}$ Warburton 1736, p. 17.

${ }^{71}$ Warburton 1736, p.54.

${ }^{72}$ Warburton 1745, p. 6.

${ }^{73}$ Warburton 1745, p. 5.
} 
As was mentioned above, Warburton admitted the lively sense of evils of human nature and stated that society was created to cure these evils and procure justice. ${ }^{74}$ Afterwards, he indicated the necessity of the alliance between church and state and regarded of both the church and state as equally essential in order to "keep Men from running into Disorder and mutual Violence". ${ }^{75}$ At this point, it will be helpful to state that Warburton was aware of the fact that religion whose object is truth demanded liberty and state whose end is peace-required submission and it seemed that they were contradictory. ${ }^{76}$ Therefore, he tried to give good reasons for the alliance he introduced. In his later sermons published after The Alliance, he defended that the state and church could serve for mutual good only if they become interdependent to each other. ${ }^{77}$ If there was "reciprocal Influence and mutual Aid" 78 between them, and if both the churchmen and political leaders had mutual confidence, then "neither the Church will abuse its [state's] privileges, nor the State leave it [church] unprotected". ${ }^{79}$ Consequently, the English establishment would be protected from religious animosities only by means of the harmony between the church and the state.

Having discussed his ideas, it could be concluded that Warburton had given an accurate theoretical justification of his main argument that:

Church shall apply its utmost influence in the service of the state; and that the state shall support and protect the church. ${ }^{80}$

Which sect or religion did Warburton define by claiming "church"? In other words, which religion should ally with the state need to be clarified in this theory. After James II had lost his throne in 1688 due to his papacy, the protestant succession began to be seen as a necessity for the social order and liberties of the English church and the society. ${ }^{81}$ Being aware of this fact, Warburton as the chief spokesperson of the established church's rationalist Whig held that the whole security of religion, laws and liberties of England depended on the succession in protestant line and the exclusion of nonconformists from the throne. ${ }^{82} \mathrm{He}$ preferred the unity of spirit in Protestantism to all other sects and religions for the sake of the establishment. It will be helpful to quote him

\footnotetext{
${ }^{74}$ Warburton 1736, p. 6.

${ }^{75}$ Warburton 1736, p. 18.

${ }^{76}$ Warburton 1766, p. iv.

${ }^{77}$ Warburton 1745, p. 6.

${ }^{78}$ Warburton 1745 , p. 5.

${ }^{79}$ Warburton 1754a, p. 190.

${ }^{80}$ Warburton 1736, p. 72.

${ }^{81}$ Watson 1863 , p. 58.

${ }^{82}$ Clark 2000, p. 111.
} 


\section{Pervin YİĞİT}

The Papist makes the State a Creature of the Church; the Erastian makes the Church a Creature of the State: The Presbyterian would regulate the Exercise of the State's Power on Church Ideas; the Free-Thinker, the Church, by Reasons of State: and, to compleat the Farce, the Quaker abolishes the very Being of a Church; and the Socinian suppresses the office of the Civil Magistrate. ${ }^{83}$

Every sect or church believed itself as the true one and wanted to introduce a party in administration. In such situations, it is necessary to decide who should have part in legislation. The state should determine which religion or sect should be the established one in the society. To be precise, an Alliance is the most effectual remedy: by establishing one Church, and giving a full Toleration to the rest, but excluding their Members from the public Administration; from the Admission into which these Disorders arise. ${ }^{84}$

This makes crystal clear that Warburton aimed to make both religious society and political society more durable by supporting their interdependence. In addition to this, it is reasonable to claim that this alliance served for the public utility, ${ }^{85}$ and the interest of the state regarding church had nothing to do with the abstract truth of particular religion. Put another way, Warburton's position had totally rested on the utility rather than the divine right.

Since Warburton believed that human naturally had freedom to choose his own religion, ${ }^{86}$ it was unjust for him to state that any religion should be either established or protected, as it was the true religion; "that the true end for which religion is established is, not to provide for the true faith, but for civil utility" ${ }^{87}$

Although he wanted to secure the established religion and prevent multiplication, fragmentation and sectarianism, he did not give a theological defence of Protestantism in this book. Therefore, in his theory, it is apparent that the truth of faith could not be used to decide which church should be established. However, according to Warburton, the state, which aimed to provide civil utility, should prefer the largest of the existing religious bodies in its alliance with the church. Because, in one of his letters he stated that the state has nothing at all to do with errors in religion, nor the least right so much as to attempt to repress them. Mischiefs, indeed, I said should be repressed; but by this I meant civil mischiefs arising from religious quarrels, when two churches in a tolerating country are pretty nearly equal in power (as I suppose they would soon be without a test law), and are for repressing one another's errors. ${ }^{88}$

\footnotetext{
${ }^{83}$ Warburton 1736, p. 20.

${ }^{84}$ Warburton 1736, p. 67.

${ }^{85}$ Warburton 1736, p. 74.

${ }^{86}$ According to Warburton "By the Law of Nature every Man has a Right of worshipping God according to his own Conscience". See Warburton 1736, p. 46.

${ }^{87}$ Warburton 1736, p. 148.

${ }^{88}$ Pitt 1838, 78.
} 
It is clear from his words that, the motive of the state in the alliance was not to protect religious truth and thus it should choose the numerically greatest one for the sake of public peace. ${ }^{89}$ It is worth quoting one of his letters to reinforce this point the larger the religious Society is, where there is an equality in other points, the better enabled it will be to answer the ends of the Alliance. It is scarce possible it should be otherwise, because the two Societies being composed of the same individuals, the greatly prevailing Religion must have a majority of its members in the assemblies of State, who will naturally prefer their own Religion to any other. Hence we see the reason why the Episcopal is the established Church in England; and the Presbyterian the established Church in Scotland". 90

Since the question was not related with the establishment of one particular church but the most advantageous one, all civil punishments, acts and tests were treated as the guards of social and moral well-being of the state. Thus, Warburton thought that the authority could uphold a particular religion and justly impose restrictions to the members of other religions or sects as long as these constraints served for public utility. ${ }^{91}$ In a few words, both civil punishments and exclusions from the administration had nothing to do with faith but they were supported by the idea of social utility in Warburton's theory.

It is clear from his words that, the motive of the state in the alliance was not to protect religious truth and thus it should choose the numerically greatest one for the sake of public peace. In this light, it should be stated that the established religion could not be preserved by depending on its religious truth, therefore there should be another basis for the church to rest on to maintain the continuance of its alliance with the state and to restrain non conformists for its security. For Warburton, it was the test law which gave this support to the church; "the test law was made to provide for the safety of the national church; a provision not for the sake of religion, but of civil peace". ${ }^{92}$

The Test Law was introduced by him to prevent the disturbances of different sects or religions on the established one. When threats arose in the civil society, "the Established Church demands the promised Aid of the State;

\footnotetext{
${ }^{89}$ For more information, see: Greaves 1966, p. 163; Evans 1932, p. 41. For the flexibility of this decision, see Watson 1863, p. 53; "This alliance between the State and the more numerous religious society will not be indissoluble; for it will naturally subsist only so long as the religious society, thus placed in alliance with the State, maintains its superiority in number over other religious societies". If the number of the established church decreases, "a new alliance may now be formed with such other religious society as has become the most numerous".

${ }^{90}$ Warburton 1756, pp. 308-309.

${ }^{91}$ For more information on the relation between exclusion and common good in Warburton's theory, see Miller 1994, p. 302.

${ }^{92}$ Pitt 1838, p. 78.
} 
which gives her a TEST-LAW for her security". ${ }^{93}$ In order to protect the church from religious animosities, test law was used to exclude the dissenters from the political motive in order to prevent them from injuring the allied society. Thus, Warburton's theory, which was constructed on the principle of utility, also justified the exclusion of non-conformists as a necessity for providing peace and liberty of the establishment. ${ }^{94}$

Thus, Warburton has attempted to achieve religious tranquillity to maintain the revolutionary settlement. In his theory "the necessity of religion, moral laws, the fear of God, the sanctions of rewards and punishments all serve for the preservation of the national unity". ${ }^{95} \mathrm{He}$ used religion as a means to defend commonwealth and his main motive was political worries. ${ }^{96}$ In other words, he was frightened of the decay in religion like all Anglicans. However, his main motive in his defence of protestant succession and toleration was not the theological corruption of Protestant principles but the forthcoming political outcomes of this corruption. It is hard to ignore the fact that Protestantism was under a direct threat and needed to be defended and preserved, whereas Warburton tried to secure the Anglican tradition not by means of the truth of its doctrine but by the principles of utility. This is the reason why he defended any religion not a particular one in the Alliance. ${ }^{97}$

\section{The Justification of Protestantism for Warburton}

Although, he did not pay attention to theological justification of Protestant principles in his theory introduced in Alliance and focused only on the necessity of the most advantageous religion for public utility, in his later sermons he emphasized the reasons why Protestantism was the essential element of the life, liberty and happiness of the English nation and attacked Catholicism. Let us talk about the so-called advantages of Protestantism over Catholicism for Great Britain.

Apparently, the natural superiority of the monarch was replaced by elective Parliament after the collapse of English republic in 1660. The monarch was no longer obeyed due to his divine nature but its power comes from the contract, which two parties voluntarily participated. This new legitimation of

\footnotetext{
${ }^{93}$ Warburton 1736, p. 115.

${ }^{94}$ Pitt 1838, p. 78.

${ }^{95}$ Yigit, 2017, p. 62.

${ }^{96}$ Clark 2000, p. 104.

${ }^{97}$ Regarding the defence of any religion in the eighteenth century, it could be stated that "[i]n general, we may safely assert that religion, even false religion, is the great bond of human society; that every civilized nation, in every age, has seen and felt the benefit of it, under all the mistakes and corruptions which have overspread the world". See Balguy 1817, p. 258.
} 
the authority led discussions on freedom to arise. From now on, the meaning of being a free subject took attention and the question of how it was possible to achieve and maintain a free state with free subjects turned to be the key issue. Since the aim of Warburton was to preserve social order, he was aware of the fact that he should justify the obedience to both God and King without enslaving people. When good reasons were introduced and the liberties of people were maintained, it would not be difficult to motivate people to obey the political and religious laws and achieve a peaceful society. These good reasons, Warburton believed, could be found in the principles of Protestantism.

For Warburton, there are obliquities of human nature. ${ }^{98}$ Additionally he stated that "as Superstition is sometimes found mixed with the former Weakness, viz the Love of Falsehood; so Enthusiasm, we see, has frequently its Share in this". 99 Thus, on the contrary to superstition, which signified Roman Catholicism, Protestantism was defended as the motive for people to correct the weakness of human nature and to preserve society from contamination of superstition. Furthermore, according to Warburton, enslavement to passions and vice could be replaced by the subjection to King and God and thus people became subjects of God and King without being slaves to them.

Unlike Catholicism, "King acknowledges himself created by the People" 100 in a Protestant regime. His end could only be the public good in general and he protected his subjects by the right he gained from the people not from God. This feature of the king made people to honour him, in other words; a KING, who considers the People, as his CHILDREN, of his Family and Household, is incessantly employed in feeling, supporting, and enriching those committed to his Care. So that Gratitude, which requires all the Returns of filial Duty and Affection, gives him Honour as a common Father. ${ }^{101}$

That is to say, through Protestant principles, such a legitimate King protected people and in turn, people honoured him and obeyed his rules, and thus public wealth could be achieved. However, Popery which Warburton regarded "as an impious and impudent combination against the sense and rights of mankind than as a species of religion", ${ }^{102}$ violated the rights of conscience. For Warburton, when the magistrate became a Catholic tyrant, "he naturally begins with giving up Sense and Conscience a Prey to Superstition". ${ }^{103}$ In this light, it is not hard to state that a despotic power would destroy the honour to King and

\footnotetext{
98 Warburton 1789 , p. 88.

99 Warburton 1789, p. 92.

100 Warburton 1745 , p. 15.

101 Warburton 1745, p. 13.

102 Pitt 1838, p. 78.

103 Warburton 1745, p. 7.
} 


\section{Pervin YİĞİT}

weakened the submission of subjects. Therefore, Warburton introduced the preservation of Protestantism for England's main defence against the tyranny of Catholicism.

In his sermon preached during the Jacobite threat, Warburton aimed to attack Catholicism's main principles to indicate the unreasonableness of the rebellion for English nation. He censured Catholicism as it eliminated the fear of God and caused moral disintegration in the society. As was mentioned before, to Warburton, the fear of God had very crucial role in providing social and moral order of the society. Hence, when it was taken from the civil society by means of Catholicism, obedience and honour to the King would not be rationalized and social peace would not be achieved because "POPERY entirely rooting out of the Minds of Men all Fear of the Deity; and ARBITRARY POWER, out of their Affections, all Honour of the Magistrate". ${ }^{104}$

How Catholicism swept the fear of God away? For Warburton, firstly, Catholicism removed the relation between god and human "by transferring much of the Worship due to the Creator upon the Creature, in their Idolatrous Adoration of dead Men". ${ }^{105}$ Idolatry was to banish the fear of God since it turned the idea of God into a worthless human-like idea in the imaginations of human. Secondly, the "Doctrine and Discipline of Penitence" of Catholicism made religious reverence lose its power in keeping man to behave according to their duty. Men were no longer afraid of God since they believed that their sins could be forgiven according to popish principles. To reinforce this point, it will be helpful to quote him: in the Church of Rome, the Doctrines of Attrition with the Priest's Power to forgive Sins, quite root out all this reverential Fear, by teaching Men, that the whole Course of a wicked-ill-spent Life, is atoned for by simple Sorrow, and the Priest's Absolution at the Hour of Death. ${ }^{106}$

Thirdly, in Catholicism, God's rule and power lost its vitality since they were transferred to a Man who assumed "to himself all Power both in Heaven and in Earth". ${ }^{107}$ According to Warburton, any intermediate power was unnecessary in the relation between God and people, as religion was only a private contract made with God by each individual. Pope's spiritual sovereignty in other words Catholicism's dualist conception of two spheres of authority inevitably destroyed the authority of God. ${ }^{108}$

\footnotetext{
${ }^{104}$ Warburton 1745, p. 8 .

${ }^{105}$ Warburton 1745 , p. 9.

${ }^{106}$ Warburton 1745, p. 10.

${ }^{107}$ Warburton 1745, p. 11.

${ }^{108}$ Warburton 1754b, pp. 112-113.
} 
Fourthly, Popery took away the fear of God due to "its Tyranny over Conscience, called Submission to the Holy See". Although "[i]t is Gospel Doctrine that God alone is the Judge of Conscience", Popery brought tyrant as a judge of conscience in the place of God and damaged the idea of God. In Warburton's words, Popery "wears out of the Mind all Fear of the divine Omniscience, intent only on deceiving these fearful Tyrants over Conscience". Despite the fact that God was the sole judge as "the Soul of Piety and Guide of human Life", tyrant turned to be the judge instead of God and consequently Warburton saw the Holy Catholic Church as "a Usurpation on the Rights of the Divinity". ${ }^{109}$

After giving the reasons of why Catholicism should be regarded as a threat to the British Constitution, Warburton paid attention to the bloody and unnatural conception of the rebellion in England and he stated that such a rebellion would easily destroy the honour to the King as well as to God. ${ }^{110}$ In order to reinforce this point and to warn people against the undesired influence of Catholicism, he put stress on the differences between a legitimate king of Protestant regime and a tyrant of Catholic regime.

In England, the king owed his power to the people and was seen as a legitimate king by English nation whose end was the common wealth. ${ }^{11}$ Whereas, it turned to be a tyrant under a Catholic rule, which acknowledged him that he, claimed his rights from the supernatural power. Thus, the subjects did not obey him as free subjects like in Protestantism, rather the subjects were seen as "the People made for the Gratification of his Pleasure, and the Support of his Magnificence". ${ }^{112}$ That is, a tyrant "regard[ed] his Subjects but as SLAVES, ordained for the Execution of his Will and Pleasure", and for this reason he led them to turn their honour to hatred, distrust, jealousy and detestation ${ }^{113}$.

After the rebellion had been repressed, he preached another sermon and emphasized the relation between the spirit of Popery and slavery in contrast to the liberty of the Protestantism. ${ }^{114}$ He claimed that there were two possibilities in a state;

Either the inveterate Tyranny in Government will viciate the Purity of Religion, and introduce the same blind Submission of the Understanding, and slavish Compliance of the Will into the Church, which it exacts in the State; or else the Spirit of the Lord will break down the Barrier of an unequal despotic Policy, and bring into the State, as well as Church, a free and reasonable Service. ${ }^{115}$

\footnotetext{
${ }^{109}$ Warburton 1745 , p. 11-13.

${ }^{110}$ Warburton 1745, p. 13.

${ }^{111}$ Warburton 1745, p. 15.

112 Warburton 1745, pp. 15-16.

${ }^{113}$ Warburton 1745, pp. 13-14.

114 Warburton 1746b, pp. 1-4.

115 Warburton 1746b, p. 2.
} 
Apart from the Protestantism's role in the preservation of the liberty and life of both the state and subjects, in his later sermons preached in 1754, Warburton put more emphasis on liberty achieved through Protestant principles. To Warburton, this freedom was seen as "the Balm of human Misery, the Quintessence of human Felicity, and the best Recompense for the Loss of a Terrestrial Paradise". ${ }^{116}$ Since it could be produced only by true religion, Britons should preserve their true religion to achieve their natural and civil rights in order to maintain the British liberty and their happy constitution. ${ }^{117}$

In other words, it was the true religion, which produced the civil and religious freedom, the greatest human good, ${ }^{118}$ and it was Protestantism, which was the true religion. That is, protestant principles and civil liberty impart to one another and they had necessary connection; when civil liberty was destructed, superstition replaced it because arbitrary power required superstition's support in order to be effective. Similarly, when true religion was gone, the destruction of civil liberty necessarily followed it. ${ }^{119}$

Warburton, by indicating those differences between a legitimate king of Protestantism and a lawless tyrant of Catholicism, tried to evince the threat of arbitrary power and Catholicism for their "happy Constitution". ${ }^{120} \mathrm{He}$ recommended to the English nation to "support [their] Holy Religion against Popish Superstition; and [their] equitable Government against arbitrary Power". ${ }^{121}$ Protestant Principles were the best safeguards of the establishment through which Britons could "warm [their] Affections, purify [their] Hearts, enlighten [their] Understandings, and strengthen [their] Wills". ${ }^{122}$ In addition to this, during the rebellion when Great Britain was faced with the threat of Catholicism Warburton stated that we are presented with a blind Submission of the Understanding, and a forced Compliance of the Will; with absurd Superstitions concerning God's despotic and capricious Government, imitated, in its own, by an ambitious and corrupt Clergy, administered under the awful name of HIERARCHY; the whole concluding in Narrowness of Thought, in Lowness of Sentiment, and base and abject Conceptions of Man, created after God's own Images. ${ }^{123}$

\footnotetext{
116 Warburton 1789 , p. 93.

117 Warburton 1745, p. 18; Warburton 1746b, p. 3, 15.

${ }^{118}$ Warburton 1746b, p. 27.

${ }^{119}$ Warburton 1746b, pp. 30-31.

${ }^{120}$ Warburton 1745 , p. 16.

${ }^{121}$ Warburton 1745, pp. 17-18.

122 Warburton 1745, p. 27.

${ }^{123}$ Warburton 1746b, p. 4.
} 
According to him, Britons should prefer the rights of freeborn English people to obedience to arbitrary power, freedom of conscience to blind submission, piety to superstition, virtue to fanaticism and sense to non-sense. ${ }^{124}$ Therefore people should repress the rebellion by supporting their "glorious Constitution to which [they] have the Honour to belong". ${ }^{25}$ This obviously meant that the debate between Catholicism and Protestantism was not only related with religion but also with politics in the eighteenth century in general and with the competition between France and Great Britain in particular.

\section{Conclusion}

For Anglicans, it was necessary to re-establish and strengthen the Anglican Church in the conditions of the eighteenth century England which was changed due to the influence of the enlightenment. To this end, William Warburton as one of the most influential Anglican critic introduced to make an alliance between church and state. Warburton did not defend Protestantism only because it was the true faith but also it was the main cement of British constitution and the remedy for the fear of the loss of liberty and monarchical tyranny in eighteenth-century England.

He gave a political legitimation of Anglicanism and justified the alliance between church and state to achieve a peaceful and well-ordered Britain. $\mathrm{He}$ reconciled the interests of church and state in political issues and tried to maintain the link between doctrine and morality against all objections. Evidently, he regarded God as moral governor and author of the constitution of nature, and he used religion as a political instrument in preserving social and moral order of the society.

Since the eighteenth century was defined as the age of reason, Warburton also gave attention to reason and human's free will both in political and religious sphere. This attitude towards combining rationalism with religious enthusiasm provided the Christian interpretation of the English Enlightenment. His emphasis on the liberty of subjects also maintained a solid basis for preserving Anglican Church in the given period without introducing English Enlightenment as a rebellion to religion.

Considering English Enlightenment as a completely secular movement by ignoring the Anglican intellectuals would be incomplete. This is the reason why, William Warburton and his reformation plan that indicated the conservative and clerical character of the eighteenth century England needed to be studied to understand the peculiar character of the English Enlightenment.

\footnotetext{
124 Warburton 1745 , p. 19.

125 Warburton 1745, p. 20.
} 


\section{BIBLIOGRAPHY}

Albers 1993

Anonymous 1735

Balguy 1817

Champion, 2003

Clark 2000

Evans 1932

Fitzpatrick, 1996

Gilley 1981

Greaves 1966

Grell and Porter 2000

Haakonssen 1996

Horsley 1790

Langford 2002
Jan Albers, "'Papist traitors' and 'Presbyterian rogues': religious identities in Eighteenth-Century Lancashire" in The Church of England c. 1689- c. 1833: from toleration to Tractarianism, edited by John Walsh, Colin Haydon and Stephen Taylor, Cambridge University Press.

The Occasional Paper upon the Subject of Religion, and the Church Establishment; and the present attempts against them, London.

Thomas Balguy, Nine Discourses on various subjects: and seven charges, delivered to the Clergy of the Archdeaconry of Winchester, London.

Justin Champion, Republican Learning: John Toland and the crisis of Christian culture, 1696-1722, Manchester.

Jonathan Charles Douglas Clark, English Society 1660-1832 Religion, Ideology and Politics during the Ancient Regime, Cambridge.

Arthur William Evans, Warburton and the Warburtonians: a study in some eighteenth-century controversies, Oxford University Press.

Martin Fitzpatrick, "The Enlightenment, politics and providence: some Scottish and English comparisons", in Enlightenment and Religion- Rational Dissent in eighteenthcentury Britain, edited by Knud Hakonssen, Cambridge University Press.

Sheridan Gilley, "Christianity and Enlightenment: a historical survey", History of European Ideas.

Robert William Greaves, "The Working of the Alliance, A Comment on Warburton", in Essays in Modern English Church History, in memory of Norman Sykes, edited by G. V. Bernett and J. D. Walsh, London.

Peter Ole Grell and Roy Porter, "Toleration in Enlightenment Europe" in Toleration in Enlightenment Europe, edited by Ole Peter Grell and Roy Porter, Cambridge University Press.

Knud Haakonssen, "Enlightened Dissent: an introduction", in Enlightenment and Religion- Rational Dissent in eighteenthcentury Britain, edited by Knud Haakonssen, Cambridge University Press.

Samuel Horsley, A Review of the Case of the Protestant Dissenters with Reference to the Corporation and Test Acts, London.

Paul Langford, The eighteenth century, 1688-1815, Oxford. 
Locke 1726

Locke 1788

Miller 1994

Neill, 1958

O'Gorman 1997

Pincus 2006

Pitt 1838

Plummer 1910

Pocock 1997

Pocock 2007

Porter 1981

Sorkin 2010

Sykes 1934

Taylor 2009

Warburton 1736

Warburton 1745
John Locke, An Essay Concerning Human Understanding, London.

John Locke, A Letter Concerning Toleration, London.

Peter N. Miller, Defining the Common Good: Empire, religion and philosophy in eighteenth-century Britain, Cambridge.

Stephen Neill, Anglicanism, London.

Frank O'Gorman, The Long Eighteenth Century British Political and Social History 1688-1832, Oxford University Press.

Steven C. A. Pincus, England's Glorious Revolution: a brief history with documents, New York.

William Pitt, Correspondence of William Pitt, Earl of Chatham. v. II, edited by William Stanhope Taylor and Captain John Henry Pringle, London.

Alfred Plummer, The Church of England in the Eighteenth Century, Methuen.

J. G. A. Pocock, Enthusiasm: The Anti-self of Enlightenment, Huntington Library Quarterly.

J. G. A. Pocock, Conservative Enlightenment and Democratic Revolutions: The American and French Cases in British Perspective, Government and Opposition.

Porter Roy, "The Enlightenment in England", in The Enlightenment in National Context, edited by Roy Porter and M. Teich, Cambridge.

David Sorkin, The Religious Enlightenment: Protestants, Jews, and Catholics from London to Vienna, Princeton University Press.

Norman Sykes, Church and State in England in the eighteenth century, Cambridge University Press.

Stephen Taylor, "Robert Walpole", in Oxford Dictionary of National Biography. Available from http://www.oxforddnb.com/view/article/28601?docPos=2.

Walsh and Taylor 1993 John Walsh and Stephen Taylor, "Introduction: the Church and Anglicanism in the "long' eighteenth century", in The Church of England 1689-1833: from toleration to Tractarianism, edited by John Walsh, Colin Haydon and Stephen Taylor, Cambridge University Press.

William Warburton, The Alliance Between Church and State, 1th edition, London.

William Warburton, A Sermon Occasioned by the Present Unnatural Rebellion. Being an Earnest Exhortation to a manly 
Warburton 1746a

Warburton 1746b

Warburton 1754a

Warburton $1754 \mathrm{~b}$

Warburton 1756

Warburton 1766

Warburton 1788

Warburton 1789

Warburton 1809

Watson 1863

Wykes 1996

Yigit 2017

Young 1998 defence of our Happy Constitution in Church and State, London.

William Warburton, "Advertisement" in A Sermon Preached on the Thanksgiving for the Suppression of the Late Unnatural Rebellion, London.

William Warburton, A Sermon Preached on the Thanksgiving for the Suppression of the Late Unnatural Rebellion, London.

William Warburton, "Of Church Communion" in The Principles of Natural and Revealed Religion occasionally opened and explained in a Course of Sermons, v. II., London. William Warburton, "Of Church Authority" in The Principles of Natural and Revealed Religion occasionally opened and explained in a Course of Sermons, v. II., London.

William Warburton, A View of Lord Bolingbroke's Philosophy, Compleat, in four letters to a friend, London.

William Warburton, The Alliance Between Church and State, $4^{\text {th }}$ edition, London.

William Warburton, The Works of the Right Reverend William Warburton, edited by Richard Hurd, Volume:I-VII, London.

William Warburton, "A Critical and Philosophical Enquiry into the Causes of Prodigies and Miracles, as related by Historians" in Tracts by Warburton, and a Warburtonian, London.

William Warburton, Letters from a late eminent prelate to one of his friends, London.

John Selby Watson, The Life of William Warburton, London.

David Wykes, "The Contribution of the Dissenting Academy to the emergence of Rational Dissent" in Enlightenment and Religion-Rational Dissent in eighteenth-century Britain, edited by Knud Haakonssen, Cambridge University Press.

Pervin Yigit, "John Brown as an Independent Character from Warburton Circle", Journal of History Culture and Art Research, 6(4), 55-68.

Yigit and Özkutlu 2017 Pervin Yigit and Seyit Özkutlu, "Protestantism as the Guarantee of National Liberty in the Eighteenth Century Britain", Journal of History Culture and Art Research, 6(6), 313-327.

Brian W. Young, Religion and Enlightenment in Eighteenth Century England: theological debate from Locke to Burke, Oxford: Clarendon Press. 